\title{
The Environmental Fluctuations of some Bioactive Nutraceutical Compounds in Zilla spinosa Inhabiting Arid Habitats
}

\author{
Hemmat I. KHATTAB*, Hosny A. MOSALLAM, Amal A. MORSY, \\ Zeinab D. S. ALMARID
}

Ain Shams University, Faculty of Science, Departments of Botany, Abbassia, 11566, Cairo,

Egypt;Dr.hemmat@hotmail.com (*correspondingauthor)

\begin{abstract}
Zilla spinosa is one of the dominated woody perennial shrubs widespread in the Egyptian Red sea coastal desert, belonging to family Brassicacea. Z. spinosa is used as a folk medicine and for heating by local people. Z. spinosa inhabits arid habitats exposed to adverse climatic changes which influence the production of the bioactive natural products. The natural secondary products have significant importance for plant acclimatization to the arid habitats beside their significant practical application in medicinal, nutritive and industrial purposes. The accumulation levels of some natural products including phenols, tannins, glucosinolates, flavonoids, saponins, proanthocyanidins and cardiac glycosides were measured in $Z$. spinosa inhabiting different locations of Wadi Hagul during spring and summer seasons. The results of the current study showed that $Z$. spinosa grown in the adverse environment has adapted to cope with extreme temperature, water deficit and geoclimate changes especially in summer, by enhancing the accumulation of some antioxidant compounds including phenols, tannins, glucosinolates, flavonoids, saponins, cardiac glycosides, concomitant with increments in the total antioxidant capacity and PAL activity. Consequently, Z. spinosa shrubs inhabiting the arid environment is a promising new source of saponins, glucosinolates, cardiac glycosides, phenols and flavonoids which could participate in drug development and exploration of alternative strategies to increase productivity of wild plants.
\end{abstract}

Keywords: arid habitats, natural products, seasonal climatic changes, Zilla spinosa

\section{Introduction}

Wadis are the most prevalent ecosystems in the world mountainous deserts (Fossati et al., 1999). The wadi system such as wadi Hagul comprises various habitats (Abdel Rahman and Batanouny, 1965). Vegetation in the wadi is frequently subjected to adverse seasonal climatic changes that negatively affected their setting up, growth and development, as well as canopy level. Water supply is the most prominent factor that can influence plant metabolism and anabolism (Akınc1, 1997). Generally, water deficit stimulates the production of reactive oxygen species (ROS) in plants, which causes damage in membrane lipids, nucleic acids, proteins, pigments (Noctor et al., 2014), and consequently disturb the normal metabolic activities of plants.

Plants cope with the environmental adverse effects by modulating the production and accumulation of a number of secondary metabolites. Environmental stressors increased secondary metabolites production and accumulation on the expense of primary metabolites and growth. Therefore, alterations in the local geoclimate and seasonal changes including light, temperature and humidity affect the composition of secondary metabolites (Ramakrishna and Ravishankar, 2011). Secondary metabolites including phenolic compounds, saponins, alkaloids and other nitrogenous compounds are sometimes participating in plant defense strategies against various stresses (Ramakrishna and Ravishankar, 2011). Wahid and Close (2007) reported that phenolics significantly contributed in abiotic stress tolerance as they serve as antioxidants (Balasundram et al., 2006). The exposure to either cold or heat stresses promote overproduction of phenolic compounds in wheat plants (Khattab et al., 2012). Similarly, drought stress stimulated the production and accumulation of total phenols and flavonoids in different plant species (Emam et al. 2014; Al Hassan et al., 2015). The quantitative and qualitative variations in flavonoid content of 
Flavoparmelia caperata (L.) Hale and Physcia dubia (Hoffm.) Lettau plants were also recognized depending on growth stage, degree of senescence, season and geographical location (Chaves et al., 2003).

In addition, the production and accumulation of saponins in plants is affected by the environmental conditions including light, temperature, humidity, soil fertility, local geoclimate and seasonal changes, as well as cultivation techniques. A positive correlation between saponins concentrations and abiotic stresses was observed (De Costa $e t$ al., 2013). It was indicated that the increment in the synthesis of saponins in response to stresses, might be an indicator for their involvement in plant tolerance under sever stressful conditions (Lin et al., 2009; Szakiel et al., 2011; Mahmood et al., 2014).

Furthermore, glucosinolates are secondary metabolites which occurred in family Brassicaceae (Fahey et al., 2001; Wittstock and Halkier, 2002). The accumulation of glucosinolates is regulated by plant development and tissue type ( Reichelt et al., 2002; Brown et al., 2003) as environmental stresses (Bidart-Bouzat et al., 2005; Kim and Jander, 2007; Wentzell and Kliebensteinm, 2008). The induction of glucosinolates accumulation by drought conditions has been reported by Schreiner $e$ t al. (2009). The glucosinolate content of different plant species generally increased under drought and temperature stress conditions (Radovich et al., 2005; Schreiner et al. 2009; Justen and Fritz, 2013; Charron et al., 2005).

The synthesis and accumulation of secondary metabolites in plants is influenced by environmental conditions, such as light intensity, soil minerals, drought, salinity and seasonality (Waterman an d Mole, 1989). Hydric stress usually induced the accumulation of various secondary metabolites including glycosides (Gouvea $e t$ al., 2012). Moreover, Sahin et al. (2013) reported that cardenolide production significantly increased in Digitalis plants exposed to some nutrient deficiency.

The seasonal fluctuations in the natural secondary metabolites in Zilla plants inhabiting the arid environment are not clear. Thus, the present study aimed to elucidate the suitable environment for greater natural products accumulation. Simultaneously, it was of interest to interpret the ecophysiological roles of natural secondary metabolites in this distinct desert plant adaptive strategy. Moreover, the natural variation in the levels of secondary metabolites may explore the ecological-plant interactions with their environment and may help in providing alternative strategies to increase productivity of wild plants utilized in drug and food industries.

\section{Materials and Methods}

\section{Studyarea}

Wadi Hagul is an extensive wadi occupying the valley depression between Gebel Ataqa to the North and Gebel Kahaliya to the South, Egypt. Its main channel extends for about $35 \mathrm{Km}$ and collects drainage water on both sides. With reference to the vegetation and geological features of wadi Hagul, three main sectors may be distinguished, upstream, midstream and downstream (Fig. 1). Moreover, the climate of the wadi area has been described as arid to extremely arid (Zahran, 2010).

\section{Climate of the study area}

Climatic means of Suez metrological station were studied; the nearest station to wadi Hagul had been measured during the period between 2010-2014 to throw light on the climatic conditions prevailing in the surveyed wadi (Table 1). The climatic condition of the study areas was of the arid type, with mild winter temperatures. January was the coldest month, while July and August were the hottest ones. The relatively highest amount of annual rainfall was recorded during April, whereas the highest relative humidity value was recorded during December. Moreover, the maximum wind velocity was measured during October.

\section{Plant material}

Z. spinosa shrubs with similar age and size were collected from three main sectors (upstream, midstream and downstream) of wadi Hagul from spring (April) til summer (July) seasons, depending on the vegetative organ under study.

\section{Extraction and determination of secondary metabolites \\ Extraction}

Aerial parts and the root system of $Z$. spinosa were collected from wadi Hagul, in April (the flowering stage) and June (fruiting stage), after drying under shade for 15 days, were ground to a powder. The dried powder $(100 \mathrm{~g})$ was extracted with distilled water or ethyl alcohol, methyl alcohol, petroleum ether, ethyl acetate at $4{ }^{\circ} \mathrm{C}$. After $72 \mathrm{hr}$, the extracts were filtered and the filtrates were concentrated on rotary evaporator under reduced pressure at $30{ }^{\circ} \mathrm{C}$. Then, the crude concentrated extracts were completed to final volume with water $(30 \mathrm{ml})$ and then subjected to phytochemical analysis (Harborne, 1973). The qualitative phytochemical analysis was carried out to determine the suitable solvent for the maximum quantitative estimation of secondary metabolites.

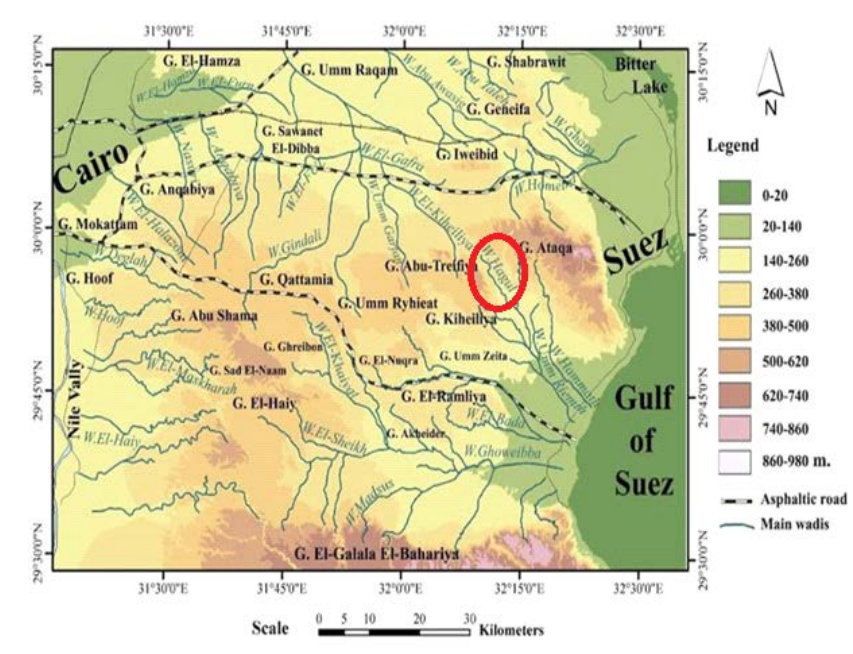

Fig. 1. Map of Cairo-Suez road showing the locations of the studied area of wadi Hagul 
496

Table 1. The meteorological data (climatic condition) of wadi Hagul during 2010-2014

\begin{tabular}{|c|c|c|c|c|c|}
\hline $\begin{array}{l}\text { Wind velocity } \\
\mathrm{Km} / \mathrm{h}\end{array}$ & Months & Relative humidity\% & Rain fall mm/month & $\begin{array}{c}\text { Mean minimum temp } \\
\left({ }^{\circ} \mathrm{C}\right)\end{array}$ & $\begin{array}{l}\text { Mean maximum temp } \\
\left({ }^{\circ} \mathrm{C}\right)\end{array}$ \\
\hline 7.02 & January & 59 & 3.4 & 10 & 20 \\
\hline 7.65 & February & 58 & 3.7 & 11 & 21 \\
\hline 7.46 & March & 54 & 3.2 & 13 & 25 \\
\hline 8.36 & April & 47 & 17.7 & 16 & 28 \\
\hline 7.46 & May & 45 & 0 & 19 & 32 \\
\hline 8.81 & June & 48 & 0 & 22 & 36 \\
\hline 7.89 & July & 52 & 0.5 & 24 & 38 \\
\hline 7.78 & August & 54 & 0 & 24 & 38 \\
\hline 8.3 & September & 56 & 0 & 22 & 34 \\
\hline 8.56 & October & 58 & 0.2 & 19 & 30 \\
\hline 6.8 & November & 60 & 1.7 & 15 & 26 \\
\hline 6.21 & December & 62 & 3.9 & 11 & 22 \\
\hline
\end{tabular}

\section{Phytochemical screening}

Phytochemical screening was carried out to test the presence of tannins, flavonoids, terpenoids, saponins, quinones and anthroquinones in all plant extracts following standard protocol of Makkar (1993).

\section{Quantitative estimation of secondary metabolites}

Measurement of total phenolics and tannins

The total phenolics and tannins were measured by using Folin-Ciocalteu method, based on the method described by Makkar et al. (1993).

Measurement of condensed tannins (Proanthocyanidins)

The total proanthocyanidins were determined by using vanillin reagent as described by Price et al. (1978). The absorbance was measured at $500 \mathrm{~nm}$ by a Shimadzu UV265 spectrophotometer (Japan).

\section{Extraction and estimation of total flavonoids content}

The aluminium chloride colorimetric method described by Harborne (1998) was used for determination of total flavonoids in the extracts. The total flavonoid contents were calculated as $\mu \mathrm{g} / \mathrm{g}$ fresh weight from standard curve of quercetin.

\section{Determination of saponins}

The total saponins was calculated from the diosgenin standard solution by using vanillin reagent according to the method of Francis et al. (2002).

\section{Determination of glucosinolate}

Glucosinolate was determined by the spectrophotometric method described by Makkar et al. (1993).

\section{Determination of cardiac gylcosides}

Cardiac glycoside content in the sample was evaluated using Buljet's reagent as described by El-Olemy (1994). 4.3.1.5

Assay of phenylalanine ammonia-lyase activity (PAL) EC

The activity of PAL was assayed as described by $\mathrm{He} e t$ al. (2001). The reaction mixture consisted of $100 \mu \mathrm{L}$ crude enzyme extract and $900 \mu \mathrm{L}$ of $6 \mu \mathrm{mol}$ phenylalanine in 500
$\mathrm{mM}$ TrisHCl buffer ( $\mathrm{pH}$ 8.5). The mixture was incubated at $37^{\circ} \mathrm{C}$ for $1 \mathrm{hr}$ and measured spectrophotometrically at $290 \mathrm{~nm}$ using UV-spectrophotometer (Spectronic 601, Milton Roy Company). PAL activity was expressed as $\mathrm{mM}$ of trans-cinnamic acid/g fresh weight $/ \mathrm{min}$.

\section{Total antioxidant capacity}

The total antioxidant capacity of the extracts was evaluated by the phosphomolybdenum method according to the procedure described by Prieto et al. (1999).

\section{Statistical analysis}

Statistical analysis was done by determining the variance and the means separated by Duncans multiple range test $(\mathrm{p}$ $>0.05$ ) as described by Snedecor and Cochran (1980). The software SAS (SAS Institute, Cary, N.C.) were used for analysis.

\section{Results}

\section{Characteristics of wadi Hagul habitats}

The restricted amounts of precipitation, associated with extremely high summer temperatures and high evaporation rates, create a harsh environment for vegetation in arid area, particularly at the Wadi's edges within the study area. The high percentage of soil moisture content was detected during the wet period of April, which was related to the fall of rain season; however, it was significantly reduced in the dry season (August). The intensification of soil water deficit in wadi Hagul during summer, particularly at the area edges (Khattab et al., 2014), was concomitant with low precipitation and high temperature (Table 2).

Seasonal qualitative and quantitative analysis of phytochemicals of Zilla spinosa parts inhabiting wadi Hagoul

Seasonal variation pronounced in different qualitative phytochemical screening of crude aqueous extracts of $Z$. spinosa parts was done to detect the presence of secondary metabolites. The extracts of Zilla aerial portions and roots revealed the presence of phenols, flavonoids, triterpenoids, steroids, alkaloids, saponins, coumarins, glucosinolate, proanthocyanidines and cardiac glycosides. The best and more relevant observed results are assayed in the aqueous extracts, particularly during the dry season, which were 
Table 2. Soil reaction, electrical conductivity and chemical analysis of soil samples from wadi Hagol, during summer (sum) and spring (spr)

\begin{tabular}{|c|c|c|c|c|c|c|c|c|c|c|c|c|}
\hline \multirow{3}{*}{ Location } & \multicolumn{2}{|c|}{$\%$ of soil water content } & \multicolumn{8}{|c|}{ Soluble cations meq } & \multicolumn{2}{|c|}{$\mathrm{CaCO}_{3} \%$} \\
\hline & \multirow{2}{*}{ Spr } & \multirow{2}{*}{ Sum } & \multicolumn{2}{|c|}{$\mathrm{Mg}^{2+}$} & \multicolumn{2}{|c|}{$\mathrm{Na}^{+}$} & \multicolumn{2}{|c|}{$\mathrm{Ca}^{2+}$} & \multicolumn{2}{|c|}{$\mathrm{K}^{+}$} & \multirow[b]{2}{*}{ Spr } & \multirow[b]{2}{*}{ Sum } \\
\hline & & & Spr & Sum & Spr & Sum & Spr & Sum & Spr & Sum & & \\
\hline \multirow{2}{*}{ Upstream } & \multirow{2}{*}{1.45} & \multirow{2}{*}{0.75} & 0.86 & 2.45 & 2.80 & 8.10 & 2.06 & 2.94 & 0.214 & 0.226 & 7.9 & 15.5 \\
\hline & & & 0.53 & 1.56 & 1.10 & 6.33 & 2.42 & 3.12 & 0.100 & 0.133 & 5.7 & 8.10 \\
\hline \multirow{2}{*}{ Midstream } & \multirow{2}{*}{2.90} & \multirow{2}{*}{2.75} & 1.98 & 4.16 & 5.43 & 12.86 & 5.40 & 6.24 & 0.214 & 0.346 & 17.3 & 19.3 \\
\hline & & & 0.12 & 0.56 & 0.37 & 0.95 & 0.296 & 0.777 & 0.100 & 0.171 & 13.1 & 14.9 \\
\hline \multirow{2}{*}{$\begin{array}{l}\text { Down } \\
\text { stream }\end{array}$} & \multirow{2}{*}{0.90} & \multirow{2}{*}{0.36} & 0.26 & 0.60 & 0.37 & 0.96 & 0.41 & 0.81 & 0.143 & 0.154 & 40.4 & 41.7 \\
\hline & & & 0.73 & 0.21 & 0.10 & 0.68 & 0.15 & 0295 & 0.100 & 0.105 & 48.7 & 51.2 \\
\hline
\end{tabular}

Table 3. Preliminary phytochemical screening of Zilla spinosa plants grown in different habitats of wadi Hagoul during spring and summer season

\begin{tabular}{|c|c|c|c|c|c|}
\hline \multirow{2}{*}{ Solvent } & \multirow{2}{*}{ Compound } & \multicolumn{2}{|c|}{ Spring } & \multicolumn{2}{|c|}{ Summer } \\
\hline & & Root & Shoot & Root & Shoot \\
\hline \multirow{11}{*}{ Water } & Phenolic & $++\mathrm{ve}$ & ++ ve & ++ ve & $+++\mathrm{ve}$ \\
\hline & Flavonoids & $+\mathrm{ve}$ & ++ ve & $+\mathrm{ve}$ & ++ ve \\
\hline & Coumarins & + ve & $+\mathrm{ve}$ & $+\mathrm{ve}$ & ++ ve \\
\hline & Triterpenoid & $+\mathrm{ve}$ & ++ ve & $+\mathrm{ve}$ & ++ ve \\
\hline & Alkaloids & $+\mathrm{ve}$ & ++ ve & + ve & ++ ve \\
\hline & Steroids & $+v e$ & ++ ve & + ve & ++ ve \\
\hline & Tannins & $+\mathrm{ve}$ & + ve & $+\mathrm{ve}$ & $+\mathrm{ve}$ \\
\hline & Saponins & ++ ve & $++\mathrm{ve}$ & +++ ve & ++ ve \\
\hline & Cardiac glycosides & ++ ve & +++ ve & ++ ve & +++ ve \\
\hline & Glucosinolate & ++ ve & ++ ve & ++ ve & +++ ve \\
\hline & Acid & $+\mathrm{ve}$ & $+\mathrm{ve}$ & $+\mathrm{ve}$ & + ve \\
\hline \multirow{11}{*}{ Ethy lalcohol } & Phenolic & $+\mathrm{ve}$ & ++ ve & $+\mathrm{ve}$ & ++ ve \\
\hline & Flavonoids & $+\mathrm{ve}$ & ++ ve & $+\mathrm{ve}$ & ++ ve \\
\hline & Coumarins & $+\mathrm{ve}$ & $+\mathrm{ve}$ & $+\mathrm{ve}$ & ++ ve \\
\hline & Triterpenoid & $+\mathrm{ve}$ & $+\mathrm{ve}$ & $+\mathrm{ve}$ & $+\mathrm{ve}$ \\
\hline & Alkaloids & - ve & - ve & - ve & - ve \\
\hline & Steroids & $+\mathrm{ve}$ & $+\mathrm{ve}$ & $+\mathrm{ve}$ & $+\mathrm{ve}$ \\
\hline & Tannins & - ve & - ve & - ve & - ve \\
\hline & Saponins & + ve & + ve & $+\mathrm{ve}$ & + ve \\
\hline & Cardiac glycosides & $+\mathrm{ve}$ & ++ ve & $+\mathrm{ve}$ & ++ ve \\
\hline & Glucosinolate & + ve & ++ ve & $+\mathrm{ve}$ & ++ ve \\
\hline & Acid & $+\mathrm{ve}$ & $+\mathrm{ve}$ & $+\mathrm{ve}$ & $+\mathrm{ve}$ \\
\hline \multirow{11}{*}{ Methyl alcohol } & Phenolic & ++ ve & $++\mathrm{ve}$ & $++\mathrm{ve}$ & $+++\mathrm{ve}$ \\
\hline & Flavonoids & $+\mathrm{ve}$ & ++ ve & $+\mathrm{ve}$ & $++\mathrm{ve}$ \\
\hline & Coumarins & $+\mathrm{ve}$ & + ve & + ve & +++ ve \\
\hline & Triterpenoid & $+\mathrm{ve}$ & $+\mathrm{ve}$ & $+\mathrm{ve}$ & $+\mathrm{ve}$ \\
\hline & Alkaloids & - ve & - ve & - ve & - ve \\
\hline & Steroids & $+\mathrm{ve}$ & $+\mathrm{ve}$ & $+\mathrm{ve}$ & $+\mathrm{ve}$ \\
\hline & Tannins & - ve & - ve & - ve & - ve \\
\hline & Saponins & $+\mathrm{ve}$ & $+\mathrm{ve}$ & $+\mathrm{ve}$ & + ve \\
\hline & Cardiac glycosides & $+\mathrm{ve}$ & $+\mathrm{ve}$ & $+\mathrm{ve}$ & $+\mathrm{ve}$ \\
\hline & Glucosinolate & ++ ve & ++ ve & ++ ve & ++ ve \\
\hline & Acid & $+\mathrm{ve}$ & + ve & $+\mathrm{ve}$ & + ve \\
\hline \multirow{11}{*}{ Petroleum ether } & Phenolic & $+\mathrm{ve}$ & ++ ve & $+\mathrm{ve}$ & $+\mathrm{ve}$ \\
\hline & Flavonoids & $+\mathrm{ve}$ & ++ ve & $+\mathrm{ve}$ & $+\mathrm{ve}$ \\
\hline & Coumarins & - ve & - ve & - ve & - ve \\
\hline & Triterpenoid & $+\mathrm{ve}$ & $++\mathrm{ve}$ & $+\mathrm{ve}$ & $++\mathrm{ve}$ \\
\hline & Alkaloids & - ve & - ve & - ve & - ve \\
\hline & Steroids & $+\mathrm{ve}$ & $\mathrm{e}$ & + ve & + ve \\
\hline & Tannins & - ve & - ve & - ve & - ve \\
\hline & Saponins & $+\mathrm{ve}$ & $+\mathrm{ve}$ & $+\mathrm{ve}$ & $+\mathrm{ve}$ \\
\hline & Cardiac glycosides & + ve & + ve & + ve & + ve \\
\hline & Glucosinolate & $+\mathrm{ve}$ & $+v e$ & + ve & $+\mathrm{ve}$ \\
\hline & Acid & + ve & $+\mathrm{ve}$ & + ve & $+\mathrm{ve}$ \\
\hline
\end{tabular}


498

thereafter used in the quantification of the secondary metabolites (Table 3). The greater qualitative secondary metabolites contents were detected in $Z$. spinosa aerial portions as compared with their roots. Therefore, the secondary metabolites levels were measured in the aerial portions along wadi Hagul habitats.

\section{Quantitative analysis of secondary metabolites}

The important secondary metabolites such as phenolics, flavonoids, saponins, tannins, proanthocyanidines and glucosinolates were quantified by using spectrophotometric assay.

\section{Seasonal and spatial variation in total phenols}

$Z$. spinosa aerial portions accumulated higher amount of total phenols in dry summer season compared to those harvested in spring (Table 4). The greatest levels of phenols accumulation were observed in Zilla aerial portions inhabiting the edges of the wadi, particularly at the downstream locations, during the dry season.

\section{Seasonal and spatial variation in flavonoids}

The quantitative estimation of the seasonal and spatial changes in the total flavonoids illustrated that Zilla aerial portions exhibited greater levels of flavonoids during summer seasons (Table 4). The maximum levels of flavonoids were measured in Zilla aerial portions inhabiting upstream and downstream wadi Hagul during summer season.

\section{Seasonal and spatial variation in tannins}

$Z$. spinosa aerial portions attained higher tannins levels in the dry season, particularly at the edges of the wadi (Table 4). The aerial portions of Zilla plants exhibited greater amounts of tannins during summer seasons. In addition, the maximum value of tannins level was attained in downstream inhabiting Zilla aerial portions during the summer season.

\section{Seasonal and spatial variation in proanthocyanidines} (condensed tannins)

The amount of pro-anthocyandines was significantly increased in Zilla aerial portions harvested in the dry season compared to those of spring. The maximum increase in the accumulation of pro-anthocyanidines was measured in Zilla aerial portions inhabiting the edges of wadi Hagul during dry periods (Table 4). However, the increment in the total pro-anthocynidines was more pronounced in Zilla inhabiting the downstream during summer season.

Seasonal and spatial changes in saponins

Saponins are the most common secondary metabolites accumulated in Zilla aerial portions (Table 5). It was noticed that the highest amount of saponins was observed in Zilla aerial portions inhabiting the downstream location followed by the first location during the dry season compared with this of the second stand.

\section{Seasonal and spatial changes of glucosinolates}

The total glucosinolates content increased significantly in summer harvested Zilla aerial portions particularly at the edges of wadi Hagul (Table 5). The maximum amount of glucosinolates was achieved in Zilla aerial portions located downstream the wadi $(6318.42 \mu \mathrm{g} / \mathrm{g} \mathrm{dw})$.

\section{Seasonal and spatial variation in cardiac glycosides}

Data presented in Table 5 clearly indicated that the accumulation of total cardiac glycosides was greater in Zilla aerial portions during summer season. The maximum increase in cardiac glycosides was attained in Zilla aerial portions grown at the edges of wadi Hagul specially at the third location, in summer.

Table 4. Seasonal changes in total phenols, flavonoids, total tannins and proanthocyanidines ( $\mu \mathrm{g} / \mathrm{g} \mathrm{dw})$ contents of Zilla spinosa aerial portions grown in different habitats of wadi Hagul

\begin{tabular}{cccccc}
\hline \multirow{2}{*}{ Season } & \multirow{2}{*}{ Location } & \multicolumn{4}{c}{ Parameter $\left(\mu \mathrm{g} \mathrm{g}^{-1}\right)$} \\
\cline { 2 - 5 } & & Total phenols & Flavonoids & Tannins & Pro-anthocyanidines \\
\hline \multirow{3}{*}{ Spring } & Upstream & $3623.74 \pm 75.63^{\mathrm{c}}$ & $3386.10 \pm 174.62^{\mathrm{c}}$ & $211.77 \pm 5.55^{\mathrm{d}}$ & $242.65 \pm 1.63^{\mathrm{bc}}$ \\
& Midstream & $2147.47 \pm 67.76^{\mathrm{d}}$ & $876.67 \pm 133.67^{\mathrm{c}}$ & $176.51 \pm 14.22^{\mathrm{c}}$ & $558.82 \pm 1.63^{\mathrm{a}}$ \\
& Downstream & $2723.23 \pm 36.5^{\mathrm{cd}}$ & $2634.17 \pm 178.47^{\mathrm{d}}$ & $224.02 \pm 4.66^{\mathrm{d}}$ & $248.37 \pm 1.25^{\mathrm{bc}}$ \\
& Upstream & $5622.90 \pm 11.80^{\mathrm{b}}$ & $5874.98 \pm 38.8^{\mathrm{b}}$ & $295.20 \pm 4.115^{\mathrm{b}}$ & $214.22 \pm 4.71^{\mathrm{c}}$ \\
\multirow{3}{*}{ Summer } & Midstream & $4292.93 \pm 77.2^{\mathrm{c}}$ & $1754.12 \pm 32.1^{\mathrm{de}}$ & $248.00 \pm 12.31^{\mathrm{c}}$ & $356.21 \pm 2.87^{\mathrm{b}}$ \\
& Downstream & $83^{8} 7.21 \pm 89.2^{\mathrm{a}}$ & $6318.42 \pm 46.2^{\mathrm{a}}$ & $520.95 \pm 6.44^{\mathrm{a}}$ & $177.94 \pm 1.47^{\mathrm{c}}$ \\
\hline
\end{tabular}

Each value is a mean of three replicates \pm SD

Table 5. Seasonal changes in glucosinalates, cardiac glycosides, saponins, the total antioxidant capacity and PAL activity of Zilla spinosa aerial portions grown in different habitats of wadi Hagul

\begin{tabular}{|c|c|c|c|c|c|c|}
\hline \multirow[b]{2}{*}{ Season } & \multirow[b]{2}{*}{ Location } & \multicolumn{5}{|c|}{ Parameter } \\
\hline & & $\begin{array}{l}\text { Saponins } \\
\left(\mu g^{-1}\right)\end{array}$ & $\begin{array}{l}\text { Glucosinolates } \\
\qquad\left(\mu g^{-1}\right)\end{array}$ & $\begin{array}{l}\text { \% of cardiac } \\
\text { glycosides }\end{array}$ & $\begin{array}{l}\text { Total antioxidant } \\
\text { capacity }\left(\mu \mathrm{g} \mathrm{g}^{-1}\right)\end{array}$ & $\begin{array}{c}\text { PAL (mM of trans- } \\
\text { cinnamic acid } / \mathrm{g} \mathrm{FW} / \mathrm{min} \text { ) }\end{array}$ \\
\hline \multirow{3}{*}{ Spring } & Upstream & $14762.00 \pm 48.01^{a}$ & $5276.87 \pm 38.8^{c}$ & $1.180 \pm 0.022^{\mathrm{a}}$ & $0.020 \pm 0.0008^{c}$ & $0.70 \pm 0.067^{b}$ \\
\hline & Midstream & $7084.00 \pm 29.14^{c}$ & $4819.24 \pm 38.7^{\mathrm{cd}}$ & $0.38 \pm 0.023^{\mathrm{bc}}$ & $0.004 \pm 0.0004^{\mathrm{e}}$ & $0.41 \pm 0.007^{\mathrm{c}}$ \\
\hline & Downstream & $9775.00 \pm 38.15^{b}$ & $5877.79 \pm 38.8^{b}$ & $0.54 \pm 0.015^{b}$ & $0.010 \pm 0.0022^{\mathrm{d}}$ & $0.66 \pm 0.01^{\mathrm{b}}$ \\
\hline \multirow{3}{*}{ Summer } & Upstream & $5016.00 \pm 38.15^{\mathrm{e}}$ & $5874.99 \pm 32.1^{\mathrm{b}}$ & $0.58 \pm 0.011^{\mathrm{b}}$ & $0.043 \pm 0.0008^{\mathrm{a}}$ & $0.81 \pm 0.007^{\mathrm{b}}$ \\
\hline & Midstream & $3696.00 \pm 38.14^{\mathrm{f}}$ & $5754.12 \pm 38.8^{b}$ & $0.41 \pm 0.009^{b c}$ & $0.0274 \pm 0.0004^{b}$ & $0.51 \pm 0.008^{c}$ \\
\hline & Downstream & $8844.00 \pm 38.10^{\mathrm{b}}$ & $6318.42 \pm 23.5^{a}$ & $1.26 \pm 0.004^{\mathrm{a}}$ & $0.045 \pm 0.0 .0004^{\mathrm{a}}$ & $1.1 \pm 0.01^{\mathrm{a}}$ \\
\hline
\end{tabular}


Seasonal and spatial variation in PAL activity

In addition, the increments in PAL activity was more pronounced in aerial portions inhabiting the edges of wadi Hagul particularly at the third downstream stand during summer followed by the first location during spring (Table 5).

Seasonal and spatial variation in the total antioxidant capacity

The total antioxidant values of aqueous extracts of $Z$ illa aerial portions were greater in the three investigated sites during summer season. It was obvious from the obtained data that the greatest magnitude of the total antioxidant value was measured in Zilla aerial portions inhabiting the third stand particularly during the dry period (Table 5).

\section{Discussion}

The mountainous desert is characterized by aggressive climatological condition. The restricted amounts of freshwater, in combination with extremely high summer temperatures and high evaporation rates, creates a harsh habitat for vegetation. Topography affects soil type and thus habitat and weather pattern including fluctuation in seasonal temperature and precipitation (Ruggiero et al., 1994), as well as soil moisture level across arid environment (Walker, 2000). In addition, the spatial pattern plays a central role in plant community dynamics including succession, adaptation, maintenance of species density and competition, as well as biomass (Sofy and Mohamed, 2012). Woody plants exhibit marked seasonal metabolic fluctuations triggered by day length, light intensity, temperature extremes and thereby reduction in soil moister content and plant water status particularly during the dry season (Larcher, 2003; Ramakrishna and Ravishankar, 2011). The synthesis and accumulation of secondary metabolites including phenols, flavonoids, saponins, tannins, glucosinolate and cardiac glycosids fluctuated seasonally in the arid environment inhabiting plants.

The preliminary qualitative secondary metabolites screening of the crude extracts of Zilla was done to assess the presence of bioactive components. The stem and root extracts of $Z$. spinosa have revealed the presence of phenols, flavonoids, saponins, steroids, glucosinolate, cardiac glycosides, tannins and alkaloids, detected generally, in all used solvents. However, in the present investigation all the screened secondary metabolites were found to be better extracted by water. Seasonal variation was pronounced in different secondary metabolites content of Zilla inhabiting wadi Hagul. The environmental stressors pushed all metabolic processes towards the synthesis of secondary metabolites as isoprenoids, phenols, flavonoids or alkaloids due to the closure of stomata and consequently reduction in the endogenous $\mathrm{CO} 2$ level and the consumption of reduction equivalents $\left(\mathrm{NADPH}^{+} \mathrm{H}^{+}\right)$utilized in the $\mathrm{CO} 2-$ fixation via Calvin cycle (Ramakrishna and Ravishankar, 2011; Al-Gabbiesh et al., 2015).

In addition, the quantitative analysis indicated that phenols accumulated in relatively large amounts in Zilla spinosa aerial portions inhabiting the edges of wadi Hagul particularly during the dry season. This can be possibly be related to the depletion of soil moisture content at the edges of wadi Hagul and the unfavorable environmental conditions (high temperature and strong light radiation). The accumulation of phenolics in stressed plants may be due to the activation of their biosynthesis and/or inhibition of their oxidation, which could be an acclimation mechanism of the plant against stress (Kefeli et al., 2003). Likewise, water stress can stimulate the accumulation of phenolic compounds in desert plants in summer season by hydrolyzing the glycosides (Gehlot et al., 2011). Moreover, the spatial variations in phenols accumulation were parallel to the changes in PAL activity in Zilla aerial portions inhabiting different locations along wadi Hagul during spring and summer seasons. Arbona et al. (2013) reported that heat induced PAL activity and the production of phenolic and at the same time reduced their oxidation, contributing to heat stress acclimation. Polyphenol synthesis and accumulation is generally stimulated in response to biotic or abiotic stresses (Muthukumarasamy $e t$ al., 2000; Rajabbeigi et al., 2013; Patel and Patel, 2014). Phenolic compounds confer ROS scavenging ability (Pokorny et al., 2001; Saeed et al., 2012) and enhanced plant tolerance under harsh environmental conditions. Likewise, the longer exposure to stronger sunlight stimulated phenols biosynthesis (Sezai et al., 2008). Furthermore, deficiencies in nutrients in wadi Hagul habitats, particularly during summer, led to the accumulation of phenol precursor, phenyl propanoids and lignification (Dixon and Paiva, 1995) and thus induced plant acclimation against stress (Arbona et al., 2013).

In addition, flavonoids are one of the main phenolic compounds of plants which have potent antioxidant activities (Bravo, 199; Nunes et al., 2012) and thus, they are involved in the protection of plants against stresses (Winkel-Shirley, 2001). Summer harvested Z. spinosa aerial portions attained greater amount of flavonoids particularly at the third location of Wadi Hagul (downstream). The increments in the total flavonoids during the dry hot season particularly at third site may be associated to the extent of environmental stressful conditions imposed by high temperature, low soil humidity and strong solar radiation. The climatic and ecological variations, such as the duration and intensity of sunlight, have significant effect on the nature and quality of secondary plant metabolites (Sezai et al., 2008). The total flavonoids and phenolic contents increased in Melilotus indicus and Lactuca sativa L. exposed to abiotic stresses (Ahmed et al., 2012; Rajabbeigi, et al., 2013). Flavonoids are efficient antioxidant (Tahara, 2007) and able to neutralize the reactive oxygen species under stress conditions (Gould, 2004), so nullify the stress injuries of $Z$. spinosa subjected to temporal and spatial variations. Tecomella undulate accumulated greater amount of flavonoids during summer season (Patel and Patel, 2014). Flavonoids are involved in the resistance of plant and also provide a number of functions in the ecology of plants.

Saponins, like flavonoids, tannins and terpenes, are defensive secondary metabolites that allow plants to cope with the environmental conditions (storing and conserving water, resisting predators and surviving severe weather conditions (Harlev et al., 2012). Saponin is one of the most common compounds measured in $Z$. spinosa plants. The 
500

greatest saponins level was measured in Zilla aerial portions collected during the dry period especially at the third location. The seasonal and spatial variations in saponins in Zilla may be due to the differential synthesis and/or accumulation of saponins and their aglycones, depending upon species or genotype, age and environmental conditions (Inderjit and Foy, 1999). The greatest accumulation of saponins in Zilla parts particularly at the third location was positively related to the depletion in soil moisture content (Khattab et al., 2014). This observation agreed with the results reported previously, that drought and salinity stimulated the production of total saponins in several plant species (De Costa et al., 2013). The increase in saponins levels could be related to its protective role against oxidative stress (Lin et al., 2009). Many desert plants contain substantial amounts of steroids and triterpene saponins which make them survive severe weather conditions (Ramakrishna and Ravishanker, 2011).

Glucosinolates are nitrogen and sulphur containing compounds derived from amino acids. The quantitative distribution of glucosinolates in the aerial portions was greater during the hot dry summer. $Z$. spinosa inhabiting the third location exhibited the maximum levels of glucosinolates during the dry period. The increments in glucosinolates were concomitant with the reduction in amino acids content (precursors of glucosinalates, unpublished results). Glucosinolates significantly increased in drought stressed Brassica oleracea and Brassica carinata (Radovich et al., 2005; Schreiner et al., 2009). The actual function of the accumulation of glucosinolates on a biotic stress tolerance is not known yet (Arbona et al., 2013).

Cardiac glycoside is one of the secondary metabolites which can play a role in the adaptation of plants to their environment (Sahin et al., 2013). The highest production of cardiac glycosides was recorded in Zilla aerial portions inhabiting wadi Hagul edges. The levels of cardiac glycosides accumulation were negatively related to the total soluble sugars levels in Zilla grown at the three locations along wadi Hagul (unpublished results). The increments in the cardiac glycosides might be related to the reduction in the rate of plant tissues growth which concomitant with the depletion in nutrient and soil moisture content. The depletion in cardiac glycosides in Zilla grown midstream might be attributed to the increase in soil moisture and nutrients, which participate in fast growth rate. Such results are similar to those reported by Sahin et al. (2013) who noted that deficiencies in $\mathrm{Ca}$ and $\mathrm{Mg}$ results in the greater accumulation of cardenolides in Digitalis species. The synthesis and accumulation of secondary metabolites such as cardiac glycosides is affected by abiotic environmental factors such as light intensity, soil minerals, osmotic stresses (drought and salinity) and seasonality (Waterman and Mole, 1989).

The activation of PAL enzyme is a common response of plant cells to biotic and abiotic stresses and may also function as antioxidants and play a major role in secondary metabolites biosynthesis (Haslam, 1998). PAL activity was markedly increased in summer harvested Zilla aerial portions particularly at downstream. The increments in PAL activity were concomitant with increments in total phenols and flavonoids. Similar results have been reached by Sung et al. (2005), Ashraf (2011) and Rajabbeigi et al. (2013). PAL plays a key role in linking primary metabolism to secondary metabolism, particularly of phenylpropanoid metabolism (Zon et al., 2002).

The seasonal and spatial changes in the activity and total levels of antioxidants in Zilla aerial portions can be estimated. The greatest reducing antioxidant power measured in the third location harvested Zilla aerial portions during the dry period was concomitant with the increments in the magnitudes of the antioxidants such as phenols, flavonoids and tannins which may suggest the involvement of antioxidants in the main strategy of adaptation of Zilla to arid environment. Similar results have been reached by Ahmed et al. (2012) who observed increments in the total antioxidant capacity of Melilotus indicus extract harvested during the hot dry season, which might be due to the greater accumulation of antioxidants including phenols and flavonoids. Similarly, phenolic acids and flavonoids were the major contributors for the increments in the total antioxidant activity in Torilis leptophylla (Saeed et al., 2012). Phenols and flavonoids have been shown to be highly effective scavengers of most oxidizing molecules (Nunes et al., 2012).

\section{Conclusions}

The greatest accumulation in natural bioactive secondary metabolites which serve as antioxidants was attained in $Z$. spinosa experienced dry hot summer environment. Consequently, $Z$. spinosa is a promising new source of nutraceutical molecules which can be utilized in food and drug industries.

\section{References}

Abdel Rahman AA, Batanouny KH (1965). Vegetation and root development in the different microhabitats in Wadi Hof. Bulletin de l'Institut d'Egypte 15:55-66.

Ahmed P, Azooz MM, Prasad MNV (2012).Ecophysiology and responses of plants under salt stress. Springer, New York.

Agrell J, Oleszek W, Stochmal A, Olsen M, Anderson P (2003). Herbivoreinduced responses in alfalfa (Medicago sativa). Journal of Chemical Ecology 29:303-320.

Akınci S (1997). Physiological responses to water stress by Cucumis sativus L. and related species. $\mathrm{PhD}$ Thesis, University of Sheffield, UK.

Al Hassan M, Fuertes M M, Sánchez FJ R, Vicente O, Boscaiu M (2015). Effects of salt and water stress on plant growth and on accumulation of osmolytes and antioxidant compounds in cherry tomato. Notulae Botanicae Horti Agrobotanici43(1):1-11.

Al-Gabbiesh A, Kleinwächter M, Selmar D (2015). Influencing the contents of secondary metabolites in spice and medicinal plants by deliberately applying drought stress during their cultivation. Jordan Journal of Biological Sciences 8(1):1-10.

Arbona V, Manzi M, de-Ollas C, Ǵmez-Cadenas A (2013). Metabolomics as a tool to investigate abiotic stress tolerance in plants. International Journal of Molecular Sciences 14(3): 4885-4911.

Ashraf G (2011). Effects of drought on the activity of phenylalanine ammonia lyase in the leaves and roots of maize inbred. Journal of Applied Sciences Research 7(9):952.

Balasundram N, Sundram K, Samman S (2006). Phenolic compounds in plants and agri-industrial by-products: Antioxidant activity, occurrence, and potential uses. Food Chemistry 99:191-203. 
Bekerecioglu M, Tercan M, Ozyazgan I (1998). The effect of Gingko biloba extract (Egb 761) as a free radical scavenger on the survival of skin flaps in rats. Scandinavian Journal of Plastic and Reconstructive Surgery and Hand Surgery 32(2):135-139.

Bidart-Bouzat MG, Mithen R, Berenbaum MR (2005). Elevated $\mathrm{CO}_{2}$ influences herbivory-induced defense responses of Arabidopsis thaliana. Oecologia 145:415-424.

Bravo L (1998). Polyphenols: chemistry, dietary sources, metabolism, and nutritional significance. Nutrition Reviews 56(11):317-333.

Brown CE, Pezeshki SR, De Laune RD (2006). The effects of salinity and soil drying on nutrient uptake and growth of Spartina alterniflora in a simulated tidal system. Environmental and Experimental Botany 58(13):140-148.

Brown PD, Tokuhisa JG, Reichelt M, Gershenzon J (2003). Variation of glucosinolate accumulation among different organs and developmental stages of Arabidopsis thaliana. Phytochemistry 62:471-481.

Chaves M M, Maroco JP, Pereira JS (2003). Understanding plant responses to drought-from genes to the whole plant. Functional Plant Biology 30(3):239-264.

Charron CS, Saxton AM, Sams CE (2005). Relationship of climate and genotype to seasonal variation in the glucosinolate-myrosinase system I: Glucosinolate content in ten cultivars of Brassica oleracea grown in fall and spring seasons. Journal of the Science of Food and Agriculture 85:671-681.

De Costa F, Yendo AC, Fleck JD (2013). Accumulation of a bioactive triterpene saponin fraction of Quillaja brasiliensis leaves is associated with abiotic and biotic stresses. Plant Physiology Biochemistry 66:56-62.

Dixon RA, Paiva NL (1995). Stress-induced phenylpropanoid metabolism. The Plant Cell 7(7):1085.

Ehleringer JR, Cooper TA (1992). On the role of orientation in reducing photoinhibitory damage in photosynthetic-twig desert shrubs. Plant Cell andEnvironment 15(3):301-306.

El-Olemyl MM, Al-Muhtadi FJ, Afin AA (1994). Experimental phytochemistry. A Laboratory Manual, College of Pharmacy, King Saud University.

El-Toumy SA, EL Sharabasy F, Ghanem H, El Kady, Kassem A (2011). Chemical constituents and pharmacological activities of Zilla spinosa. Planta Medica 77:PM51.

Emam MM, Khattab H, Helal NM (2014). Effect of selenium and silicon on yield quality of rice plant grown under drought stress. Australian Journal ofCropScience 8(4):596-605.

Fahey JW, Zalcmann AT, Talalay P (2001). The chemical diversity and distribution of glucosinolates and isothiocyanates among plants. Phytochemistry 56:5-51.

Fossati J, Pautou G, Peltier JP (1999). Water as resource and disturbance for Wadi vegetation in a hyper arid area Wadi Sannur, Eeatern Desert, Egyptian. Journal of Arid Environments 43(1): 63-77.

Francis G, Kerem Z, Makkar HPS, Becker K (2002). The biological action of saponins in animal systems: A review. British Journal of Nutrition 88(6):587-605.

Gehlot M, Kasera PK, Hussian S (2011). Secondary metabolites produced during different seasons in some arid medicinal plants. Journal of Medicinal and Aromatic Plant Sciences 33: 404-406.

Golawska S, Leszczynski B, Oleszek W (2006). Effect of low and highsaponin lines of alfalfa on pea aphid. Journal of Insect Physiology 52:737-
743.

Gould KS (2004). Nature's Swiss army knife: The diverse protective roles of anthocyanins in leaves. Bio Med. Research International 5:314320.

Gouvea DR, Gobbo-Neto L, Lopes NP (2012). The influence of biotic and abiotic factors on the production on secondary metabolites in medicinal plants. In: Cechinel-Filho V (Ed). Plant Bioactives and Drug Discovery. John Wiley \& Sons, Inc, New York, NY,USA pp 519-452.

Harborne JB (2012). Phytochemical methods. London, New York, Chapman and Hall Vol 278.

Harlev E, Nevo E, Lansky EP, Lansky S, Bishayee A (2012). Anticancer attributes of desert plants: a review. Anti-Cancer Drugs 23(3):255-271.

Haslam E (1998). Practical polyphenolics: From structure to molecular recognition and physiological action. Cambridge University Press..

He C, Hsiang T, Wolyn DJ (2001). Activation of defense responses to Fusarium infection in Asparagus densiflorus. European Journal of Plant Pathology 107(5):473-483.

Inderjit NF, Foy CL (1999). Nature of the interference mechanism of mugwort (Artemisia vulgaris). Weed Technology 176-182.

Jensen CR, Mogensen V, Mortensen G, Fieldsen J,Milford G, Andersen M, Thage J (1996). Seed glucosinolate, oil and protein contents of fieldgrown rape (Brasica napus L.) affected by soil drying and evaporative demand. Field Crops Research 47:93-105.

Justen VL, Fritz VA (2013). Temperature-induced glucosinolate accumulation is associated with expression of BrMYB transcription factors. HortScience 48:47-52.

Kim JH, Jander G (2007). Myzus persicae (green peach aphid) feeding on Arabidopsis induces the formation of a deterrent indole glucosinolate. The Plant Journal 49:1008-1019.

Kefeli VI, Kalevitch MV, Borsari B (2003). Phenolic cycle in plants and environment. Cell and Molecular Biology 2:13-18.

Khattab HI, Emam MM, Abd El-Razek A (2012). Responses of wheat genotypes pretreated with paclobutrazol to temperature stresses. Egyptian Journal of Botany 52(2):115-124.

Khattab I H, El-Shishtawy HM, Musallam HA, Morsy AA, Almarid ZDS (2014). Seasonal and spatial variations in the genetic diversity of Zilla spinosa (L.) Inhabiting Wadi Hagul as revealed by rAPD markers. Egyptian Journal of Experimental Biology (Botany) 10(2):115-124.

Larcher W (2003). Physiological plant ecology. Ecophysiology and Stress Physiology of Functional Groups. Springer.

Larsson S, Bjorkman C, Gref R (1986). Responses of Neodiprion sertifer (Hym., Diprionidae) larvae to variation in needle resin acid concentration in Scots pine. Oecologia 70(1):77-84.

Le Roux A, Schelpe T (1998). Namaqualand South African wild fower guide I. Botanical Society of South Africa, Claremont. Physiologia Plantarum 69(1):147-150.

Lin Z, Zhong S, Grierson D (2009). Recent advances in ethylene research. Experimental Botany 60(12):3311-3336.

Liu F, Jensen CR, Shahanzari A, Andersen MN, Jacobsen SE (2005). ABA regulated stomatal control and photosynthetic water use efficiency of potato Solanum tuberosum L. during progressive soil drying. Plant Science 168(3):831-836.

Mahmood S, Parveen A, Hussain I, Javed S, Iqbal M (2014). Possible involvement of secondary metabolites in the thermotolerance of maize seedlings. International Journal of Agriculture and Biology 16:10751082. 
502

Makkar HP, Blümmel M, Borowy NK, Becker K (1993). Gravimetric determination of tannins and their correlations with chemical and protein precipitation methods. Journal of the Science Food and Agriculture 61(2):161-165.

Morison JIL, Lawlor DW (1999). Interactions between increasing CO2 concentration and temperature on plant growth. Plant Cell Environment 22:659-682.

Muthukumarasamy M, GuptaSD, Panneerselvam R(2000). Enhancement of peroxidase, polyphenol oxidase and superoxide dismutase activities by triadimefon in $\mathrm{NaCl}$ stressed Raphanus sativusL. Biologia Plantarum 43(2):317-320.

Noctor G, Mhamdi A, Foyer C H (2014). The roles of reactive oxygen metabolism in drought. Plant Physiology 164:1636-1648.

Nunes X P, Silva FS, Almeida JRGS, Lima JT, Ribeiro LAA, QuintansJunior LJ, Barbosa Filho J M (2012). Biological oxidations and their role in nutrition and health. Venketeshwer R(Ed). InTech Publisher.

Odjegba VJ, Alokolaro AA (2013). Simulated drought and salinity modulates the production of phytochemicals in Acalypha wilkesiana. Journal of Plant Studies 2(2):105-112.

Patel AK, Patel IC (2014). Seasonal effects on some phytochemicals accumulation of Tecomella undulate (SM.) seem. Advance Research in Pharmaceuticals and Biologicals 4(1):639-643.

Piper CS (2001). Soil and plant and analysis. University of Adelaide Press. Australia, 1950,pp 368.

PokornyJ, Yanishlieva N, Gordon M (2001). Antioxidants in food: practical applications. Cambridge Woodhead Publishing Limited 72(5):145171.

Price M L, Van Scoyoc S, Butler LG (1978). A critical evaluation of the vanillin reaction as an assay for tannin in sorghum grain. Journal of Agricultural and Food Chemistry 26(5):1214-1218.

Prieto P, Pineda M, Aguilar M (1999). Spectrophotometric quantitation of antioxidant capacity through the formation of a phosphomolybdenum complex: specific application to the determination of vitamin $\mathrm{E}$. Analytical Biochemistry 269(2):337-341.

Radovich TJK, Kleinhenz MD, Streeter JG (2005). Irrigation timing relative to head development influences yield components, sugar levels, and gucosinolate concentrations in cabbage. Journal of the American Society for Horticultural Science 130:943-949.

Rajabbeigi E, Eichholz I, Beesk N, Ulrichs Ch, Kroh LW, Rohn S, Huyskens-Keil S (2013). Interaction of drought stress and UV-B radiation - impact on biomass production and flavonoid metabolism in lettuce (Lactuca sativa L.). Journal of Applied Botany and Food Quality 86:190-197.

Ramakrishna A, Ravishankar GA (2011). Influence of abiotic stress signals on secondary metabolites in plants. Plant Signal Behaviors 6(11):17201731.

Reichelt M, Brown PD, Schneider B, Oldham NJ, Stauber E, Tokuhisa J, Kliebenstein DJ, Mitchell-Olds T, Gershenzon J (2002). Benzoic acid glucosinolate esters and other glucosinolates from Arabidopsis thaliana. Phytochemistry 59:663-671.

Richards LA (1954). Diagnosis and improvement of saline and alkali soil, US Salinity LabStaff,USDA Handbook, Washington DC, USA.

Ruggiero LF, Hayward GD, Squires JR (1994). Viability analysis in biological evaluations: Concepts of population viability analysis, biological population, and ecological scale. Conservation Biology 8:364372.

Ryan J, Garabet S, Harmson K, Rashid A (2012). A soil and plant analysis. Manual adapted for the West Asia and North Africa region. ICARDA, Aleppo, Syria
Saeed N, Khan MR, Shabbir M (2012). Antioxidant activity, total phenolic and total flavonoid contents of whole plant extracts Torilis leptophylla (L.). BMC Complementary and Alternative Medicine 12(1):221-232.

Sahin G, Verma SK, Gurel E (2013). Calcium and magnesium elimination enhances accumulation of cardenolides in callus cultures of endemic Digitalis species of Turkey. Plant Physiology and Biochemistry 73:139143.

Schreiner M, Beyene B, Krumbein A, Stützel H (2009). Ontogenetic changes of 2-propenyl and 3-indolylmethyl glucosinolates in Brassica carinata leaves as affected by water supply. Journal of Agricultural and Food Chemistry 57:7259-7263.

Sezai E, Emine O, Ozlem O, Memnune S, Gungor N (2008). Seasonal variation of total phenolic, antioxidant activity, plant nutritional elements, and fatty acids in tea leaves (Camellia sinensis var. sinensis clone derepazari 7) grown in turkey. Pharmaceutical Biology 46(10-11):683687.

Snedecor GW, Cochran WG (1980). Statistical Methods (7th Ed). State University Press, Ames, Iowa.

Sofy MR , Mohamed AA (2012). Plant metabolites responses to spatial variation in South Sinai. Egypt. Universal Journal of Environmental Research and Technology 2(6):529-536.

Sung Y, Chang Y, Ting N (2005). Capsaicin biosynthesis in water stressed hot pepper fruits. Botanical Bulletin of Academia Sinica 46:35-42.

Szakiel A, Paczkowski C, Henry M (2011). Influence of environmental abiotic factors on the content of saponins in plants. Phytochemistry Reviews 10:471-91.

Tahara S (2007). A journey of twenty-five years through the ecological biochemistry of flavonoids. Bioscience, Biotechnology and Biochemistry 71(6):1387-1404.

Teklay T (2004). Seasonal dynamics in the concentrations of macronutrients and organic constituents in green and senesced leaves of three agroforestry species in southern Ethiopia. Plant and Soil 267(12):297-307.

Udden JA (1914). Mechanical composition of clastic sediments. Geological Society of America Bulletin 25(1):655-744.

Wahid A, Close TJ (2007). Expression of dehydrins under heat stress and their relationship with water relations of sugarcane leaves. Biologia Plantarum 51(1):104-109.

Walker DA (2000). Hierarchical subdivision of Arctic tundra based on vegetation response to climate, parent material and topography. Global Change Biology 6(S1):19-34.

Waterman PG, Mole S (1989). Extrinsic factors influencing production of secondary metabolites in plants. Insect-plant interactions 1:107-134.

Wentzell AM, Kliebenstein DJ (2008). Genotype, age, tissue, and environment regulate the structural outcome of glucosinolate activation. Plant Physiology 147(1):415-428.

Winkel-Shirley B (2001). Flavonoid biosynthesis. A colorful model for genetics, biochemistry, cell biology and biotechnology. Plant Physiology 126(2):485-493.

Wittstock U, Halkier B A (2002). Glucosinolate research in the Arabidopsis era. Trends in Plant Science 7(6):263-270.

Zahran MA (2010). Climate-vegetation and human welfare in the coastal deserts. In: Climate-Vegetation. SpringerNetherlands pp 249-295.

Zoń J, Amrhein N, Gancarz R (2002). Inhibitors of phenylalanine ammonia-lyase:1-aminobenzylphosphonic acids substituted in the benzene ring. Phytochemistry 59(1):9-21. 